cable to the existing case without any manner of doubt. The mystery of the great ice age, and of the former rich vegetation in the present cold zone, still remains to be solved.

Frank WaLdo.

An Outline of the Theory of Solutions, and Its Results, for Chemists and Electricians. By J. Livingston R. Morgan, Рн.D. (Leipzig), Instructor in Quantitative Analysis, Polytechnic Institute, Brooklyn. New York, John Wiley \& Sons; London, Chapman \& Hall. 1897. Pp. 63.

The contents of this work are four lectures, delivered before the Brooklyn Institute of Arts and Sciences, and deal with the theory of solutions, methods for the determination of electrolytic dissociation, the theory of the voltaic cell, and analytical chemistry from the standpoint of electrolytic disociation.

The author states in his preface that "a knowledge of the theory of solution and its results, is so important to workers in all branches of chemistry and electricity, that the following pages have been compiled, containing an elementary treatment of the subject." * * * "If by this sketch the author can induce any one to go deeper into the subject he will feel more than repaid for his work."

\section{H. C. J.}

Untersuchungen über das Erfrieren der Pfanzen. Molisch. Jena, Gustav Fischer. 1897. Pp. viii +73 . 11 illustrations.

A notable addition to the physiology of the cell has been recently published by Professor Molisch as a result of several years' work upon the effect of cold upon plants.

The researches upon which generalizations rest are fragmentary and necessarily inaccurate, since they were carried on in the open air or under conditions of great discomfort to the observer. At the same time no regulation of the temperature could be effected. Dr. Molisch has been enabled to obtain results of great importance, both from the advance in cell physics since the time of Muller's experiments and by the use of ingeniously constructed apparatus.

Dr. Molisch's researches were chiefly conducted by means of a double-walled freezing chamber of wood $33 \times 33 \times 27 \mathrm{~cm}$. outside meas- urements. The space of $7 \mathrm{~cm}$. between the double walls on five sides of the chamber was filled with sawdust. The center of the chamber was occupied by a zinc compartment to contain a microscope. A tubulated opening through the walls of the zinc and wooden compartments allowed access of light to the mirror, and toothed rods for adjustment of the stage, objectives and mirror extended outside the walls. The space surrounding the zinc compartment was filled with a mixture of salt and ice, by which temperatures of $4^{\circ} \mathrm{C}$. to $10^{\circ} \mathrm{C}$. were obtained in a room kept at $10^{\circ} \mathrm{C}$.

As a useful preliminary, observations were made upon the freezing of colloidal substances, emulsions, color and salt solutions. The crystals were seen to appear suddenly in a colloid, such as gelatine, and to increase in size, extracting the water from the gelatine, so that the latter shrunk into a network resembling parenchyma tissue. Some colloids return to the original condition upon thawing; others do not. Starch paste is an example of the latter. The suspended particles in an emulsion, such as latex, aggregate in the form of a network of bands upon freezing. Freezing of color and salt solutions result in the more or less complete separation of the solid and solvent.

The chief interest of the paper lies in the results of the direct and continuous observation of the freezing of living cells.

An amœba, after exposure of 25 minutes to a temperature of $9^{\circ} \mathrm{C}$., exhibited the formation of clumps of ice crystals in the plasma, and finally became a solid lump consisting of a complicated network of plasma almost devoid of water, ice crystals, vacuoles of concentrated cell-sap and air-bubbles. The slender filaments of Phycomyces froze only when the temperature fell to $-17^{\circ}$ C. The small diameter of the cells seem to be a direct adaptation against freezing. Yeast cells exhibited a shrinkage of 10 per cent., due to loss of water when the medium was frozen, but the cells were not killed at $-15^{\circ} \mathrm{C}$. The freezing of Spirogyra filaments at -3 to $-6^{\circ} \mathrm{C}$. is accompanied by a shrinkage in diameter amounting to 62 per cent. and by the final aggregation of chlorophyll band and nucleus in the center of the cells. The excretion of water in this plant under low temperatures may be easily observed 